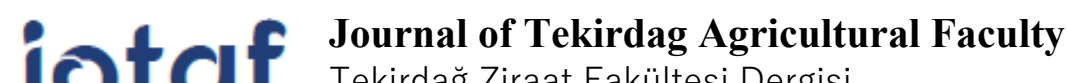 \\ Tekirdağ Ziraat Fakültesi Dergisi
}

\section{Infrared Drying Kinetics and Color Qualities of Organic and Conventional Sweet Red Peppers}

\author{
Organik ve Konvansiyonel Tatlı Kırmızı Biberlerin Kızılötesi Kurutma Kinetiği ve Renk \\ Kalitesi
}

\section{Aysel ARSLAN ${ }^{1}$, Yurtsever SOYSAL ${ }^{2 *}$, Muharrem KESKIN ${ }^{3}$}

\begin{abstract}
This study compares the infrared drying kinetics, effective moisture diffusivity, activation energy and color qualities of organically and conventionally produced sweet red peppers (Capsicum annum L.) dried at three different temperatures $\left(60,70\right.$ and $\left.80^{\circ} \mathrm{C}\right)$. Results showed that the entire drying process for both organic and conventional sweet red peppers took place mainly in falling rate period. Increasing the drying temperature decreased the drying time considerably. No significant difference was found between the drying times of organic and conventional red peppers. The Midilli model yielded the best fit for all data points for organic and conventional peppers. The drying coefficient of the Midilli model increased with the increase in the drying temperature. The effective moisture diffusivity and activation energy values of organic pepper samples were found slightly higher than those of the conventional samples. This result was found to be compatible with the drying coefficient of Midilli model and characteristic drying rate curves. Higher drying temperatures resulted in brighter red pepper powder color which is more preferable by consumers. Infrared drying at $60^{\circ} \mathrm{C}$ for organic pepper samples produced the best pepper powders in terms of color quality. Moreover, infrared drying at $60^{\circ} \mathrm{C}$ and $70^{\circ} \mathrm{C}$ was also judged as the acceptable drying applications in terms of color quality since they gave the nearest redness to yellowness ratios and higher brightness values as compared to the color of fresh peppers. Overall, infrared drying at $70^{\circ} \mathrm{C}$ instead of $60^{\circ} \mathrm{C}$ resulted in about $22 \%$ savings in drying time and can be used to produce high quality organic or conventional sweet red pepper powder with better color quality.
\end{abstract}

Keywords: Red pepper, Infrared drying, Organic food, Moisture diffusivity, Activation energy, Color quality

\footnotetext{
$2 *$ Sorumlu Yazar/Corresponding Author: Yurtsever Soysal, Department of Biosystems Engineering, Faculty of Agriculture, Hatay Mustafa Kemal University, 31060, Antakya, Hatay, Turkey. E-mail: yurtsever.soysal@gmail.com DOrcID: 0000-0003-0871-8570

1 Aysel Arslan, Department of Biosystems Engineering, Faculty of Agriculture, Hatay Mustafa Kemal University, 31060, Antakya, Hatay, Turkey. E-mail: aysel.arslan.hty@gmail.com (D) OrcID: 0000-0002-0060-0263.

${ }^{3}$ Muharrem Keskin, Department of Biosystems Engineering, Faculty of Agriculture, Hatay Mustafa Kemal University, 31060, Antakya, Hatay, Turkey.E-mail: mkeskinhatay@gmail.com (D) OrcID: 0000-0002-2649-6855.

Atıf/Citation: Arslan, A., Soysal, Y., Keskin, M. 2020. Infrared Drying Kinetics and Color Qualities of Organic and Conventional Sweet Red Peppers. Tekirda Ziraat Fakültesi Dergisi, 18 (2), 260-272.
} 


\section{Özet}

$\mathrm{Bu}$ çalışmada, üç farklı sıcaklıkta $\left(60,70\right.$ ve $\left.80^{\circ} \mathrm{C}\right)$ kurutulan organik ve geleneksel olarak üretilen tatlı kırmızı biberlerin (Capsicum annum L.) kızılötesi kurutma kinetikleri, efektif nem difüzyonu, aktivasyon enerjisi ve renk kaliteleri karşılaştırılmıştır. Araştırma sonucunda, organik ve geleneksel tatlı kırmızı biberlerin kızı̈ötesi kurutma sürecinin tamamının temel olarak azalan hızlı kurutma periyodunda meydana geldiği saptanmıştır. Kurutma sıcaklığındaki artışa bağlı olarak ürün kuruma süresi önemli ölçüde kısalmıştır. Organik ve geleneksel kırmızı biberlerin kurutma süreleri arasında anlamlı bir fark bulunmamıştır. Organik ve konvansiyonel biberlerin kuruma davranışına ilişkin tüm verilerin matematiksel olarak ifade edilmesinde Midilli modelinin in iyi sonuçları veren model olduğu belirlenmiştir. Midilli modelinin kurutma katsayısının kurutma sıcaklığındaki artışa bağlı olarak arttı̆̆ 1 saptanmıştır. Organik biber örneklerinin efektif nem difüzyonu ve aktivasyon enerjisi değerlerinin geleneksel biber örneklerine ait değerlerden biraz daha yüksek olduğu belirlenmiştir. Bu sonucun Midilli modelinin kurutma katsayısı ve karakteristik kurutma hızı eğrileri ile uyum içinde olduğu saptanmıştır. Yüksek sıcaklıklarda kızılötesi kurutma ile tüketiciler tarafından daha çok tercih edilen, daha parlak renkte toz kırmızı biberler üretilebileceği belirlenmiştir. Organik biber örnekleri için $60^{\circ} \mathrm{C}$ 'de kızılötesi kurutma uygulaması ile ürün renk kalitesi bakımından en iyi kırmızı toz biberlerin üretilebileceği saptanmışır. Ayrıca, taze kırmızı biberlerin rengine en yakın renk kırmızılı̆̆ oranlarına ve taze kırmızı biberlerden daha yüksek parlaklık değerlerine sahip olan kırmızı biber tozları ürettikleri için, $60^{\circ} \mathrm{C}$ ve $70^{\circ} \mathrm{C}$ sıcaklıklarda kızılötesi ile kurutma uygulamaları da renk kalitesi bakımından kabul edilebilir kurutma uygulamaları olarak değerlendirilmiştir. Sonuç olarak, $60^{\circ} \mathrm{C}$ yerine $70^{\circ} \mathrm{C}$ 'de kurutma uygulaması ile ürün kurutma süresinde yaklaşı $\% 22$ tasarruf sağlamış olup, bu uygulamanın yüksek kaliteli organik veya geleneksel tatlı toz kırmızı biber üretmek için kullanılabileceği saptanmıştır.

Anahtar Kelimeler: Kırmızı biber, Kızılötesi kurutma, Organik gıda, Nem difüzyonu, Renk kalitesi 


\section{Introduction}

Increasing awareness on human, plant, and animal health as well as environment has created an expanding organic food market. Coinciding with this, consumers' demands for dried organic foods are also increasing and dried organic products are offered for sale at higher prices compared to traditional products and become more and more visible on supermarkets. Organic products have higher antioxidant activity, higher concentrations (18-69\%) of desirable antioxidants/(poly) phenolics and other plant secondary metabolites linked to reduced chronic and neurodegenerative diseases and certain cancers and also, 75\% and 48\% lower concentrations of agrochemical residues and Cadmium, respectively (Gomiero, 2018). Organic farming has an increasing trend both in the world (31.5 million ha in 2007 and 69.8 million ha in 2017) and in Turkey (0.17 million ha in 2007 and 0.54 million ha in 2017) (Anonymous, 2018; Lernoud and Willer, 2019). However, there have been only a few studies in the literature comparing the drying kinetics and quality of organically or conventionally grown fruits and vegetables. Sablani et al. (2011) studied the effects of hot-air and freeze drying on the phytochemical content and moisture diffusivity of conventional and organic berries and reported that some organic varieties (Meeker1 and Duke) showed higher moisture diffusivity whereas the trend was inverse for the other pairs (Meeker2 and Reka) as compared to conventional berries. In another research, freeze drying, air-drying and flash freezing treatments were compared with respect to total phenolic and ascorbic acid contents of some products (marionberry, strawberry and corn) grown by conventional, organic and sustainable agricultural practices (Asami et al., 2003). Nevertheless, no study was found to explore the drying characteristics of red peppers.

Red pepper (Capsicum annuum L.) is an important cash crop all over the world and is widely consumed as fresh or dried. It is used in food industry for the production of spices, pastes, natural colorants, soups, sauces and oleoresin (Soysal et al., 2009). The total global pepper production was about 36.1 and 2.6 million tonnes in the world and in Turkey, respectively (Anonymous, 2019a). Organic production of pepper is also important in Turkey with about 5558 tons in 2018 (Anonymous, 2019b).

Like many other agricultural crops, fresh pepper fruit is highly perishable as it contains moisture up to $90 \%$ (wet basis). Drying is one of the most widely applied and relatively cost-effective postharvest processing method to extent the shelf life of red pepper by reducing the water activity to a safe storage limits to inhibit microbial activity and many of the moisture-originated degradation reactions (Arslan and Ozcan, 2011; Şahin et al., 2012; Aktaş et al., 2013; Deng et al., 2018). The primary quality characteristic of dried red pepper is red color intensity (Kim et al., 2002; Ergunes and Tarhan, 2006; Topuz et al., 2011). Like all other fruits and vegetables, characteristic color of red pepper originates from carotenoids (Deng et al., 2018) and is highly sensitive to post-harvest processing conditions such as hot-air or natural sun drying (Soysal et al., 2005; Di Scala and Crapiste, 2008; VegaGálvez et al., 2008; Soysal et al., 2009; Vega-Gálvez et al., 2009). Moreover, composition of carotenoids which controls the color of pepper fruits largely depends on the variety, stage of ripening, cultivation practices and geoclimatic conditions (Arimboor et al., 2015).

Traditional sun drying and hot-air drying are still the most commonly used methods of drying to produce dried red pepper flakes and powders. However, they have several drawbacks like lengthy drying time, contamination issues, inability to process large quantities without impairing product quality, manual labor requirements, low energy efficiency, low product quality due to prolonged exposure to high temperatures (Vega-Gálvez et al., 2008; Soysal et al., 2009; Doymaz and Kocayigit, 2012). Infrared heating technique is presented as one of the most promising method of drying to obtain the high quality dried fruits, vegetables and grains (Pawar and Pratape, 2017). It can be considered as an artificial sun-drying process (Chua and Chou, 2003) as versatile, fast responsive, easily installable and a low-cost drying technology with simple equipment requirement (Sandu, 1986). Compared to conventional drying methods, infrared drying has higher energy efficiency, shorter drying time and superior product quality (Nasiroglu and Kocabiyik, 2009; Onwude et al., 2016). Also, it can be used alone in a continuous or intermittent mode or easily coupled with convective, conductive and microwave heating (Pawar and Pratape, 2017). However, high drying temperatures or energies may result in lower quality dried product even if they shorten the drying time (Keskin et al., 2018; Keskin et al., 2019). Infrared energy as part of electromagnetic spectrum can be transferred to the sample surface directly without heating the surrounding air and has the potential to save energy up to $50 \%$ as compared to convective drying (Nowak and Lewicki, 2004). 
Literature review revealed that studies on the comparison of drying kinetics and color parameters of organic and conventional products have been very limited. To the best of authors' knowledge, no detailed study comparing the infrared drying kinetics and color quality of organically and conventionally grown sweet red pepper exists in the literature. Hence, the aim of this study was to evaluate the efficacy of infrared drying on the drying kinetics and color quality attributes of organically and conventionally produced same type sweet red peppers and to model the infrared drying kinetics data mathematically using non-linear regression technique.

\section{Materials and Methods}

\subsection{Pepper samples}

In this research, sweet red pepper (Capsicum annum L., Capia type, Diyar F1 cultivar) produced in organic and conventional farming methods under greenhouse conditions near Erdemli city (36.6115N, 34.2624E) of Mersin province, Turkey were used. This pepper type is intensively produced and consumed in Turkey. The pepper samples which were hand harvested in the red stage were stored at $+4^{\circ} \mathrm{C}$ until drying experiments. The wet based (w.b.) moisture contents of the peppers were determined by using standard oven method by drying at $103^{\circ} \mathrm{C}$ for $24 \mathrm{~h}$. Before each drying experiment, three pepper samples were used for moisture content analysis. The average initial moisture contents of the organic and conventional pepper samples were $91.25 \% \pm 0.0 .68$ (w.b.) and $91.96 \% \pm 0.64$ (w.b.), respectively.

\subsection{Infrared drying procedure}

An infrared dryer and moisture analyzer (Ohaus MB45 Moisture Analyzer, OHAUS, Pine Brook, NJ, USA) were used to perform drying experiments. This device is equipped with a $400 \mathrm{~W}$ halogen infrared heater and transmits medium to shortwave infrared radiation. For sample preparation, the pepper samples were washed with tap water and then rinsed with distilled water and then they were dripped and shredded with about $1.43 \pm 0.09 \mathrm{~mm}$ thickness. In each drying process, shredded pepper samples were placed homogeneously in a layer of $6.7 \pm 0.05 \mathrm{~mm}$ over the entire sample pan. 35 drying trials for each of the organic (OSRP) and conventionally grown sweet red peppers (CSRP) were performed for each of the three temperature levels $\left(50,60\right.$ and $\left.70^{\circ} \mathrm{C}\right)$ and average values at respective temperature levels were evaluated in the data analysis. Experiments were performed at about $24^{\circ} \mathrm{C}$ room temperature in an acclimatized laboratory. Mass of the pepper samples with initial loads of about $15 \mathrm{~g}$ were automatically recorded at one-minute interval with an accuracy of $0.001 \mathrm{~g}$. The drying experiments were ended at about $0.10 \mathrm{~kg}\left(\mathrm{H}_{2} \mathrm{O}\right) \mathrm{kg}^{-1}(\mathrm{DM})$ moisture content. The dried products were cooled and put into glass jar for further analysis.

\subsection{Mathematical modeling}

The experimental data were fitted to eleven different thin layer drying models to determine the most suitable drying equation (Table 1).

Table 1. Mathematical models applied to the drying curves of the organic and conventional sweet red peppers

\begin{tabular}{|c|c|c|}
\hline Model name & Model equation* & References \\
\hline 1 Newton & $M R=\exp (-k t)$ & Ertekin and Yaldiz (2004) \\
\hline 2 Page & $M R=\exp \left(-k t^{n}\right)$ & Diamente and Munro (1993) \\
\hline 3 Henderson and Pabis & $M R=a \exp (-k t)$ & Ertekin and Yaldiz (2004) \\
\hline 4 Logarithmic & $M R=a \exp (-k t)+b$ & Yagcioglu et al. (1999) \\
\hline 5 Midilli et al. & $M R=a \exp \left(-k t^{n}\right)+b t$ & Midilli et al. (2002) \\
\hline 6 Wang and Singh & $M R=1+a t+b t^{2}$ & Wang and Singh (1978) \\
\hline 7 Logistic & $M R=b /(1+a \exp (k t))$ & Jain and Pathare (2004) \\
\hline 8 Two term & $M R=a \exp (-k t)+b \exp \left(-k_{1} t\right)$ & Jain and Pathare (2004) \\
\hline 9 Verma et al. & $M R=a \exp (-k t)+(1-a) \exp (-b t)$ & Verma et al. (1985) \\
\hline 10 Two term exponential & $M R=a \exp (-k t)+(1-a) \exp (-k a t)$ & Soysal et al. (2006) \\
\hline 11 Diffusion approximation & $M R=a \exp (-k t)+(1-a) \exp (-k b t)$ & Soysal et al. (2006) \\
\hline
\end{tabular}


The equilibrium moisture content $\left(M_{e}\right)$ was assumed to be zero (Ertekin and Heybeli, 2014; Soysal et al., 2018) and, the moisture ratio $(M R)$ was simplified to $M / M_{0}$ instead of $\left(M-M_{e}\right) /\left(M_{0}-M_{e}\right)$. Non-linear regression analyses were carried out by using SigmaPlot program (Version 12). The coefficient of determination $\left(R^{2}\right)$, residual sum of squares $(R S S)$ and standard error of estimate $(S E E)$ parameters were utilized to select the best model.

\subsection{Calculation of effective moisture diffusivity and activation energy}

The experimental drying data for the determination of effective moisture diffusivity $\left(D_{\text {eff }}\right)$ were interpreted by using the Fick's second diffusion equation. General solution of Fick's second law in slab geometry was employed with the assumptions of moisture migration by diffusion, negligible shrinkage, constant diffusion coefficients and temperature using the following equation 1 (Crank, 1975):

$$
M R=\frac{M-M_{e}}{M_{0}-M_{e}}=\frac{8}{\pi^{2}} \sum_{i=0}^{\infty} \frac{1}{(2 i+1)^{2}} \exp \left[\frac{(2 i+1)^{2} \pi^{2} D_{e f f} t}{4 L^{2}}\right]
$$

Where $M R$ is the moisture ratio, $M$ is the moisture content, $M_{0}$ is the initial moisture content, $M_{e}$ is the equilibrium moisture content, $D_{\text {eff }}$ is the effective moisture diffusivity $\left(\mathrm{m}^{2} \mathrm{~s}^{-1}\right), L$ is the half thickness of the samples $(\mathrm{m}), i$ is a positive integer and $t$ is time (s).

For long drying periods, Eq. (2) can be further simplified as follows (Wang et al., 2007):

$$
\ln (M R)=\frac{8}{\pi^{2}}-\frac{\pi^{2} D_{e f f}}{4 L^{2}} t
$$

The $D_{\text {eff }}$ values were interpreted by plotting experimental $\ln (M R)$ data versus drying time since the plot gives a straight line with a slope equal to $K=\pi^{2} D_{\text {eff }} / 4 L^{2}$. An Arrhenius type equation 3 was used to describe the temperature dependency of effective moisture diffusivity as given below (Doymaz and Ismail, 2011):

$$
D_{\text {eff }}=D_{0} \exp \left(-E_{a} / R T\right)
$$

Then, taking natural logarithm of both sides, the equation can be written in a linear form as follows: 4

$$
\ln \left(D_{\text {eff }}\right)=\ln \left(D_{0}\right)-\left[\left(E_{a} / R\right)(1 / T)\right]
$$

Where $E_{a}$ is the energy of activation $(\mathrm{kJ} / \mathrm{mol}), R$ is the universal gas constant $\left(8.3143 \times 10^{-3} \mathrm{~kJ} / \mathrm{mol}\right), T$ is the absolute temperature $(\mathrm{K})$ and $D_{0}$ is the pre-exponential factor of the Arrhenius equation $\left(\mathrm{m}^{2} / \mathrm{s}\right)$.

The $E_{a}$ value can be interpreted from the slope of the Eq (4) by plotting $\ln \left(D_{\text {eff }}\right)$ versus $1 / \mathrm{T}\left(K_{l}=E_{a} / R\right)$.

\subsection{Color measurement}

Color parameters of fresh and dried-powdered organic and conventional red peppers were measured with a handheld chromameter (Minolta CR-400, Osaka, Japan). In measuring the color of the samples, ground material measurement apparatus and CIE L*a*b* color model was used. The chromameter was utilized with illuminant $\mathrm{C}$ standard and calibrated using its white reflector plate before measurements. The color is expressed in three dimensions namely: L* (brightness, 0: black, 100: white), a* (redness-greenness, -60: green, +60: red) and $b^{*}$ (yellownessblueness, -60 : blue, +60 : yellow) (Keskin et al., 2017). Color change of the material was evaluated by using the $\mathrm{a}^{*} / \mathrm{b}^{*}$ ratio, total color difference $\left(\Delta \mathrm{E}^{*}\right)$ and color difference values $\left(\Delta \mathrm{L}^{*}, \Delta \mathrm{a}^{*}\right.$ and $\left.\Delta \mathrm{b}^{*}\right)$ (Soysal et al., 2009).

\section{Results and Discussion}

\subsection{Drying Kinetics Curves}

The moisture content of the samples decreased to $\left.0.10 \mathrm{~kg}_{(\mathrm{H}} \mathrm{O}\right) \mathrm{kg}^{-1}(\mathrm{DM})$ in about 99 to 175 minutes and 100 to 176 minutes depending on the drying temperature for organic (OSRP) and conventional sweet red pepper (CSRP) samples, respectively (Fig.1, Table 2). As expected, drying time diminished considerably with the increasing drying temperature. There were no significant differences in drying times of OSRP and CSRP samples dried at 60, 70, and 
$80^{\circ} \mathrm{C}$. Compared to OSRP, drying time of the CSRP samples lasted about one minute longer. This small difference may be attributed to the growing conditions of the product as a result of such factors including chemical pesticides and fertilizers applied during conventional cultivation. Winter and Davis (2006) reported that organic fruits and vegetables utilize more metabolic energy to synthesize secondary plant metabolites such as polyphenolics and antioxidants since they are not subjected to synthetic pesticides and fertilizers. About 22\% decrease in drying times of OSRP and CSRP samples could be obtainable by drying at $70^{\circ} \mathrm{C}$ instead of $60^{\circ} \mathrm{C}$. Figure 2 shows the moisture content versus drying rate curves of OSRP and CSRP samples. After a short warming-up period, drying rates decreased continuously with decreasing moisture content. All drying processes for both OSRP and CSRP samples took place mainly in the falling rate period which implies that the migration of the moisture in the red pepper samples was controlled by the diffusion mechanism (Fig. 2). Similar results have been reported by various researchers on infrared and/or infrared assisted drying of red peppers (Nasiroglu and Kocabiyik, 2009; Tunde-Akintunde et al., 2014; Cao et al., 2016; Deng et al., 2018; Soysal et al., 2018).

\subsection{Modelling of drying curves}

The experimental moisture content data were converted to moisture ratio (MR) and fitted to eleven different thin layer-drying models (Table 1). Fitting adequacy of these models were compared in terms of the statistical parameters of the residual sum of squares (RSS), the standard error of estimates (SEE) and the coefficients of determination $\left(\mathrm{R}^{2}\right)$. The best model was chosen as the one with the highest $\mathrm{R}^{2}$ value and lowest RSS and SEE values. Among the eleven drying models used in the study, the Midilli model (Model 5) gave the best fit for all experimental infrared drying data points for both organic (OSRP) and conventional sweet red pepper (CSRP) samples with the $\mathrm{R}^{2}$ values greater than 0.9985 , the SEE lower than 0.0126 and the RSS lower than 0.0212 (Table 3 and Fig. 3). Thus, the Midilli model interpreted the experimental drying data satisfactorily for infrared drying of sweet red peppers. The drying coefficient $k$ increased with the increase in drying temperature (Table 3). This result was confirmed by the drying rate data which exhibited the same trends. The established model was validated by comparing the predicted and experimental MR values of all drying experiments. The predicted data were observed to be banded on and around the straight line of the 1:1 ratio (Figure 4).
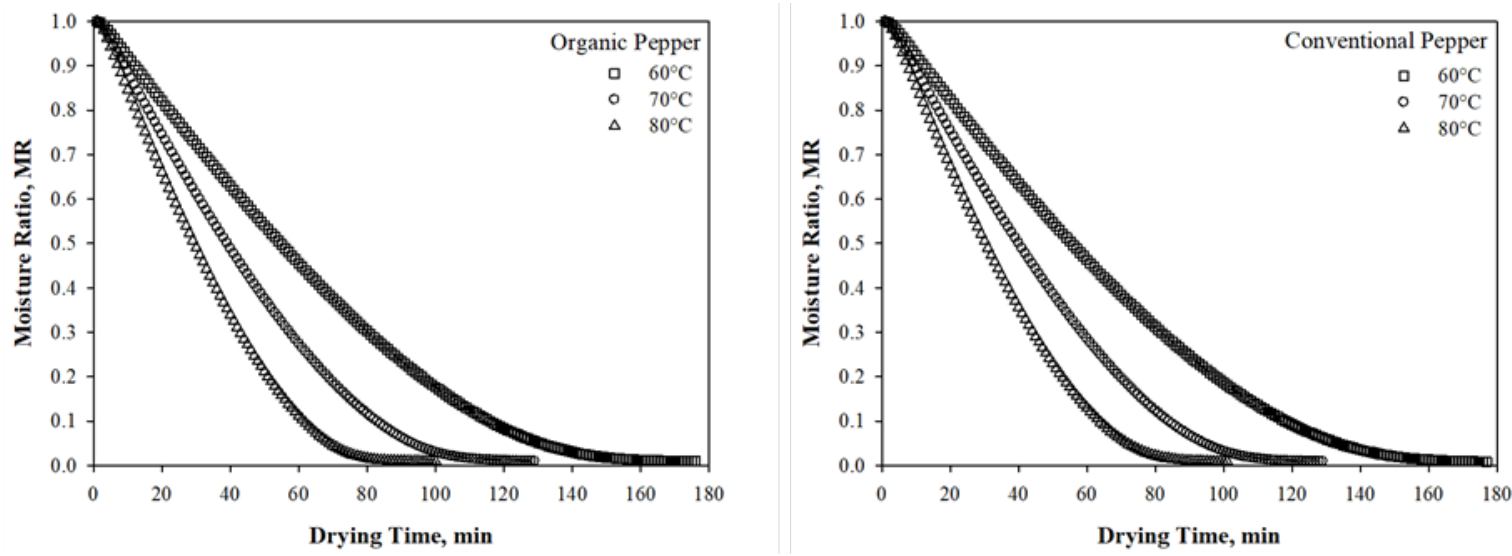

Figure 1. Infrared drying curves of organic and conventional sweet red peppers

Table 2. Drying time of each drying temperature for organic and conventional sweet red peppers

\begin{tabular}{lcc}
\hline Product Type & Drying Temperature $\left({ }^{(} \mathbf{C}\right)$ & Drying Time $(\mathbf{m i n})$ \\
\hline \multirow{3}{*}{ Organic red pepper } & 60 & $175.00 \pm 6.20^{\mathrm{a}}$ \\
& 70 & $127.57 \pm 4.07^{\mathrm{b}}$ \\
& 80 & $99.00 \pm 3.06^{\mathrm{c}}$ \\
\hline \multirow{2}{*}{ Conventional red pepper } & 60 & $176.00 \pm 7.94^{\mathrm{a}}$ \\
& 70 & $128.00 \pm 4.05^{\mathrm{b}}$ \\
\hline Different letters in same column indicate significant differences for each product type $(p<0.05)$
\end{tabular}



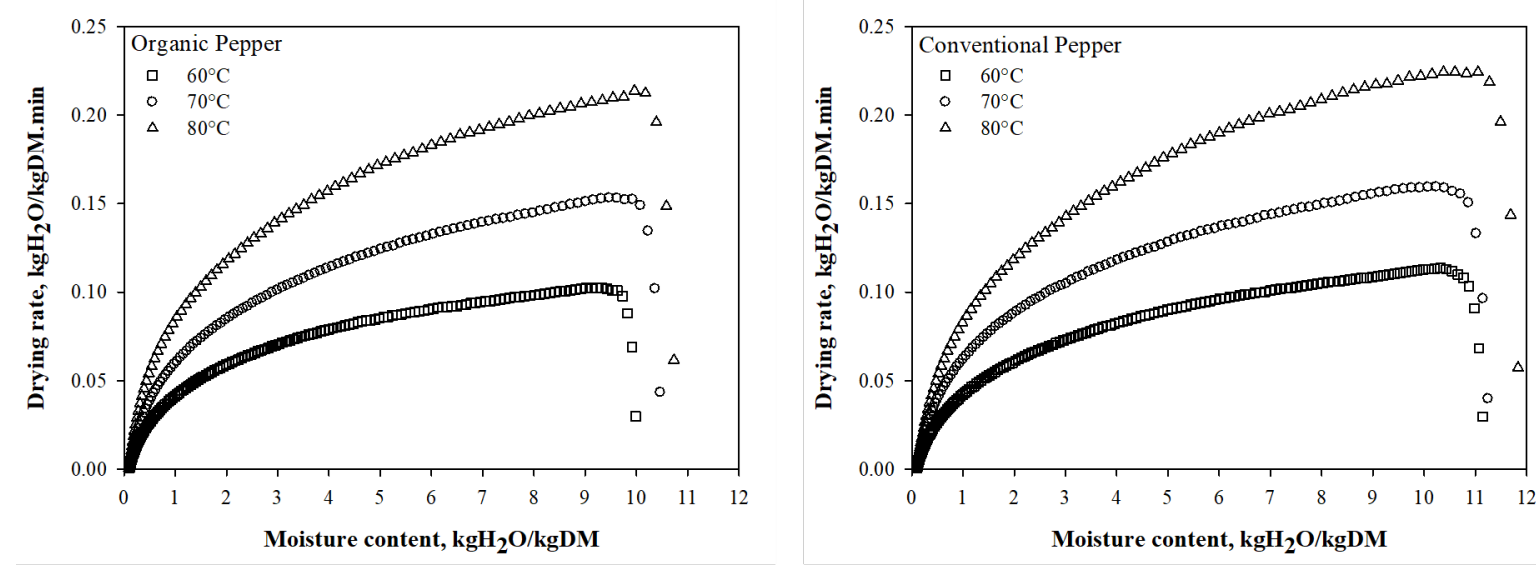

Figure 2. Infrared drying rates of organic and conventional sweet red peppers

\subsection{Modelling of drying curves}

The experimental moisture content data were converted to moisture ratio (MR) and fitted to eleven different thin layer-drying models (Table 1). Fitting adequacy of these models were compared in terms of the statistical parameters of the residual sum of squares (RSS), the standard error of estimates (SEE) and the coefficients of determination $\left(\mathrm{R}^{2}\right)$. The best model was chosen as the one with the highest $\mathrm{R}^{2}$ value and lowest RSS and SEE values (data not shown). Among the eleven drying models used in the study, the Midilli model (Model 5) gave the best fit for all experimental infrared drying data points for both OSRP and CSRP samples with the $\mathrm{R}^{2}$ values greater than 0.9985, the SEE lower than 0.0126 and the RSS lower than 0.0212 (Table 3). The drying coefficient of the Midilli model $k$ increased with the increase in drying temperature (Table 3).

Table 3. Statistical parameters and model constants for Midilli model for the infrared drying of red peppers

\begin{tabular}{lcccccccc}
\hline \multirow{2}{*}{ Product } & Drying & \multicolumn{7}{c}{ Statistical parameters and model constants } \\
\cline { 3 - 8 } & temp. $\left({ }^{\circ} \mathbf{C}\right)$ & $\boldsymbol{R}^{2}$ & $\boldsymbol{S E \boldsymbol { E }}$ & $\boldsymbol{R S S}$ & $\boldsymbol{k}$ & $\boldsymbol{n}$ & $\boldsymbol{a}$ & $\boldsymbol{b}$ \\
\hline \multirow{2}{*}{ Organic } & 60 & 0.9988 & 0.0111 & 0.0212 & 0.0022 & 1.4348 & 0.9718 & -0.0002 \\
red pepper & 70 & 0.9987 & 0.0115 & 0.0165 & 0.0036 & 1.4326 & 0.9757 & -0.0003 \\
& 80 & 0.9985 & 0.0126 & 0.0153 & 0.0047 & 1.4799 & 0.9731 & -0.0003 \\
\hline \multirow{2}{*}{ Conventional } & 60 & 0.9989 & 0.0104 & 0.0186 & 0.0022 & 1.4235 & 0.9738 & -0.0003 \\
red pepper & 70 & 0.9987 & 0.0115 & 0.0165 & 0.0036 & 1.4239 & 0.9808 & -0.0003 \\
& 80 & 0.9987 & 0.0116 & 0.0134 & 0.0045 & 1.4788 & 0.9753 & -0.0003 \\
\hline
\end{tabular}

\subsection{Effective moisture diffusivity}

All drying processes for both organic (OSRP) and conventional sweet red pepper (CSRP) samples occurred mainly in the falling rate period as shown in Figure 2. Therefore, it may be modeled as a diffusion-controlled process. The effective moisture diffusivity $\left(D_{e f f}\right)$ values for different drying temperatures $\left(60,70,80^{\circ} \mathrm{C}\right)$ are given in Table 4.

Table 4. Effective moisture diffusivity for organic and conventional sweet red peppers

\begin{tabular}{lccccc}
\hline Product & $\begin{array}{c}\text { Drying } \\
\text { temp. }\left({ }^{\circ} \mathbf{C}\right)\end{array}$ & Linear equation & $\boldsymbol{D}_{\mathbf{0}}\left(\mathbf{m}^{\mathbf{2}} \mathbf{s}^{-\mathbf{1}}\right)$ & $\boldsymbol{D}_{\text {eff }}\left(\mathbf{m}^{\mathbf{2}} \mathbf{s}^{-\mathbf{1}}\right)$ & $\mathbf{R}^{\mathbf{2}}$ \\
\hline \multirow{3}{*}{ Organic } & 60 & $\mathrm{y}=-0.000474 \mathrm{x}+0.643317$ & & $21.56 \times 10^{-10}$ & 0.947 \\
red pepper & 70 & $\mathrm{y}=-0.000679 \mathrm{x}+0.692900$ & $1.4963 \times 10^{-4}$ & $30.88 \times 10^{-10}$ & 0.953 \\
\hline \multirow{2}{*}{ Conventional } & 80 & $\mathrm{y}=-0.000890 \mathrm{x}+0.591254$ & & $40.48 \times 10^{-10}$ & 0.953 \\
red pepper & 60 & $\mathrm{y}=-0.000468 \mathrm{x}+0.653068$ & & $21.29 \times 10^{-10}$ & 0.942 \\
& 70 & $\mathrm{y}=-0.000677 \mathrm{x}+0.704413$ & $1.4964 \times 10^{-4}$ & $30.79 \times 10^{-10}$ & 0.945 \\
\hline
\end{tabular}


It was found that the $D_{\text {eff }}$ values of the pepper samples were remarkably influenced by drying temperature. Increasing the drying temperature accelerated the water molecules inside the product leading to higher vapor pressure, faster evaporation and rapid reduction in product moisture content, resulting in higher $D_{\text {eff }}$ values. This result is in good agreement with previous studies on drying of red pepper (Thuwapanichayanan et al., 2011; Darvishi, et al., 2013; Tunde-Akintunde et al., 2014; Deng et al., 2018; Soysal et al. 2018).

Depending on the drying temperature, the $D_{\text {eff }}$ values of OSRP and CSRP samples ranged from $21.56 \times 10^{-10}$ to $40.48 \times 10^{-10} \mathrm{~m}^{2} \mathrm{~s}^{-1}$ and from $21.29 \times 10^{-10}$ to $39.98 \times 10^{-10} \mathrm{~m}^{2} \mathrm{~s}^{-1}$, respectively (Table 4). The $D_{\text {eff }}$ values of the OSRP samples were found slightly higher than those of the CSRP samples. The $D_{\text {eff }}$ values were comply with the drying coefficients of Midilli model and drying rate data and both of them followed the similar trajectory. Similar findings were reported for red pepper by Cao et al. (2015). Sablani et al. (2011) conducted hot air drying experiments at $65^{\circ} \mathrm{C}$ to compare the $D_{\text {eff }}$ values of organic and conventional berries. They reported that the organic fruits had higher $D_{\text {eff }}$ values as compared to conventional fruits whereas the trend was reverse for other fruit varieties.

The pre-exponential factor of the Arrhenius equation $\left(D_{0}\right)$ was predicted as $1.4963 \times 10^{-4} \mathrm{~m}^{2} \mathrm{~s}^{-1}$ and $1.4964 \times 10^{-}$ ${ }^{4} \mathrm{~m}^{2} \mathrm{~s}^{-1}$ for the OSRP and CSRP samples, respectively (Table 4). The $D_{0}$ value denotes moisture diffusivity when temperature goes to infinity. Greater $D_{0}$ value means the weaker resistance to the diffusion (Turhan et al., 1997). $D_{0}$ value of OSRP and CSRP samples was found almost the same. This suggests that both pepper samples showed almost same resistance to the moisture removed in the product as a result of infrared drying process. The $D_{\text {eff }}$ values obtained in this study lay in general within the range of $10^{-11}-10^{-9} \mathrm{~m}^{2} \mathrm{~s}^{-1}$ as previously reported for various biological materials (Saravacos, 1986; Rizvi, 1986; Madamba et al., 1996; Maskan et al., 2002; Wang et al., 2007; Kumar et al., 2011). They were also found to be very similar (Cao et al., 2016) and higher (Deng et al, 2018; Soysal et al., 2018) than the published data for red pepper given in Table 5. The differences might be due to drying conditions, type and scale of drying equipment, proposed model used for calculation, physico-chemical properties of the product such as type, composition, tissue characteristics, thickness, cultivar and ripening stage and other uncontrolled parameters (Sanjuán et al., 2003; Darvishi et al., 2014; Deng et al., 2018).

Table 5. Comparison of data of the present study and the previous studies

\begin{tabular}{lcccl}
\hline Product and drying method & $\begin{array}{c}\text { Drying } \\
\text { temp. }\left({ }^{\circ} \mathbf{C}\right)\end{array}$ & $\begin{array}{c}\boldsymbol{D}_{\text {eff }} \\
\left(\mathbf{x} \mathbf{1 0}^{-\mathbf{1 0}} \mathbf{~ m}^{\mathbf{2}} \mathbf{s}^{\mathbf{- 1}}\right)\end{array}$ & $\begin{array}{c}\boldsymbol{E}_{\boldsymbol{a}} \\
\left(\mathbf{k J} \mathbf{~ m o l}^{\mathbf{- 1}}\right)\end{array}$ & Reference \\
\hline Organic red pepper-sliced, infrared & $60-80$ & $21.56-40.48$ & 30.85 & Present work \\
Conventional red pepper-sliced, infrared & $60-80$ & $21.29-39.98$ & 30.87 & Present work \\
\hline Red pepper-whole, infrared drying & $60-80$ & $15.8-37.8$ & 42.67 & Cao et al., 2016 \\
Red pepper-whole, infrared assisted hot air & $50-80$ & $1.75-8.97$ & 50.90 & Deng et al., 2018 \\
Red pepper-sliced, infrared & $50-70$ & $0.61-1.26$ & 33.50 & Soysal et al., 2018 \\
\hline
\end{tabular}

\subsection{Activation energy}

Activation energy $\left(E_{a}\right)$ defines the minimum energy required to initiate moisture diffusion from a product (Kadam et al., 2011) and the sensitivity of diffusivity against temperature (Turhan et al., 1997). This means that the greater the $E_{a}$ values, the more sensitivity of the diffusivity to the drying temperature. $E_{a}$ values were calculated from the slope of the Eq (4) by plotting $\ln \left(D_{\text {eff }}\right)$ versus $1 / \mathrm{T}$ (slope $=E_{a} / R$ ). The $E_{a}$ values were computed as 30.85 $\mathrm{kJ} / \mathrm{mol}$ for the OSRP and $30.87 \mathrm{~kJ} / \mathrm{mol}$ for the CSRP samples (Table5). These $E_{a}$ values were within the range of $12.7-110.0 \mathrm{~kJ} / \mathrm{mol}$ which is reported for most agricultural products (Zogzas et al., 1996) and the $E_{a}$ values for red peppers reported in different studies (Table 5). The closeness of $E_{a}$ values shows that the organic pepper is as sensitive as the conventional pepper to infrared drying temperature and furthermore, organic or conventional growing practices of the same variety product did not significantly alter the $E_{a}$ values. This result is also conforming to the profiles of moisture content versus drying time and drying rate versus moisture content, the drying coefficient data of Midilli model, $D_{\text {eff }}$ and $D_{0}$ values. 


\subsection{Color quality assessment}

The color data were presented in Table 6 as the means of seven independent measurements for each sample. The mean $L^{*}, a^{*}, b^{*}$ and $a^{*} / b^{*}$ color values of fresh organic sweet red pepper (OSRP) samples were 30.93, 24.10, 22.34, 1.08 while the values for the conventional sweet red pepper (CSRP) samples were 30.18, 25.29, 21.81, 1.16 which relates to matte red color (Table 6 ). The $\mathrm{L}^{*}, \mathrm{a}^{*}$ and $\mathrm{b}^{*}$ values of fresh OSRP and CSRP samples were almost identical $(p<0.05)$. On the other hand, the $\mathrm{a}^{*} / \mathrm{b}^{*}$ ratios of fresh OSRP and CSRP samples were significantly different $(p<0.05)$ which means that the color of fresh CSRP samples was deeper in red compared to OSRP.The $L^{*}$ values of the dried samples were remarkably higher than the fresh samples which denotes that the infrared dried pepper powders were in lighter red color than the fresh ones $(p<0.05)$. The $\mathrm{L}^{*}$ values of both OSRP and CSRP samples were significantly enhanced at higher drying temperatures resulting in lighter product colors $(p<0.05)$. Similarly, except the $\mathrm{a}^{*}$ value of the CSRP sample dried at $80^{\circ} \mathrm{C}$, the $\mathrm{a}^{*}$ and $\mathrm{b}^{*}$ values of the dried samples were significantly higher than the values of the fresh samples. Similar findings regarding $L^{*}, a^{*}$ and $b^{*}$ values were reported by Nasiroglu and Kocabiyik (2009) and Keskin et al. (2018). Kim et al. (2004) and Topuz at al. (2011) reported that the red color intensity which mainly originates from ketocarotenoids, capsanthin and capsorubin formed during ripening of the pepper was used as a primary criterion in the evaluation of the quality of paprika. Moreover, Soysal et al. (2005) and Ergunes and Tarhan (2006) suggested that the red pepper with higher brightness and redness and mild yellowness values can be considered as more favourable and marketable products in view of color quality. Regarding the differences in color parameters (Table 7), a positive correlation was found between the infrared drying temperature and $\Delta \mathrm{E}^{*}$ and $\Delta \mathrm{L}^{*}$ values. The highest $\Delta \mathrm{E}^{*}$ value was found for the CSRP samples dried at $80^{\circ} \mathrm{C}$ while the lowest $\Delta \mathrm{E}^{*}$ was obtained for the OSRP samples dried at $60^{\circ} \mathrm{C}$. Beside this, higher infrared drying temperatures produced brighter red pepper powder color which is more preferable by consumers (Table 6$)$.

Table 6. Effect of infrared drying temperatures on the color parameters of sweet red peppers

\begin{tabular}{lccccc}
\hline Product type & $\begin{array}{c}\text { Drying } \\
\text { temp. }\left({ }^{\circ} \mathbf{C}\right)\end{array}$ & $\mathbf{L}^{*}$ & $\mathbf{a}^{*}$ & $\mathbf{b}^{*}$ & $\mathbf{a}^{*} / \mathbf{b}^{*}$ \\
\hline & Fresh & $30.93 \pm 0.02^{\mathrm{a}}$ & $24.10 \pm 0.03^{\mathrm{a}}$ & $22.34 \pm 0.06^{\mathrm{a}}$ & $1.08 \pm 0.00^{\mathrm{b}}$ \\
Organic & 60 & $52.69 \pm 0.81^{\mathrm{b}}$ & $34.22 \pm 0.76^{\mathrm{d}}$ & $40.34 \pm 0.82^{\mathrm{b}}$ & $0.85 \pm 0.01^{\mathrm{c}}$ \\
red pepper & 70 & $54.33 \pm 0.85^{\mathrm{c}}$ & $32.69 \pm 0.80^{\mathrm{c}}$ & $41.16 \pm 0.90^{\mathrm{bc}}$ & $0.79 \pm 0.03^{\mathrm{d}}$ \\
& 80 & $57.10 \pm 0.84^{\mathrm{d}}$ & $27.94 \pm 0.40^{\mathrm{b}}$ & $41.82 \pm 0.90^{\mathrm{c}}$ & $0.67 \pm 0.02^{\mathrm{f}}$ \\
\hline & Fresh & $30.18 \pm 0.02^{\mathrm{a}}$ & $25.29 \pm 0.04^{\mathrm{a}}$ & $21.81 \pm 0.06^{\mathrm{a}}$ & $1.16 \pm 0.00^{\mathrm{a}}$ \\
Conventional & 60 & $57.06 \pm 0.87^{\mathrm{b}}$ & $31.58 \pm 0.66^{\mathrm{c}}$ & $40.14 \pm 0.57^{\mathrm{c}}$ & $0.79 \pm 0.03^{\mathrm{de}}$ \\
red pepper & 70 & $57.58 \pm 0.73^{\mathrm{b}}$ & $30.64 \pm 0.55^{\mathrm{b}}$ & $39.96 \pm 0.38^{\mathrm{bc}}$ & $0.77 \pm 0.02^{\mathrm{e}}$ \\
& 80 & $59.26 \pm 0.80^{\mathrm{c}}$ & $25.31 \pm 0.74^{\mathrm{a}}$ & $39.55 \pm 0.68^{\mathrm{b}}$ & $0.64 \pm 0.02^{\mathrm{g}}$ \\
\hline
\end{tabular}

Different letters in same column for organic and conventional peppers indicate significant differences $(p<0.05)$

The color redness and brightness parameters of the infrared dried pepper powders did not decrease but remarkably improved as compared to fresh product (Table 7).

Table7. Effect of infrared drying temperatures on the difference in color parameters of sweet red peppers

\begin{tabular}{ccccccc}
\hline Product type & $\begin{array}{c}\text { Drying } \\
\text { temp. }\left({ }^{\circ} \mathbf{C}\right)\end{array}$ & $\Delta \mathbf{L}^{*}$ & $\Delta \mathbf{a}^{*}$ & $\mathbf{\Delta} \mathbf{b}^{*}$ & $\mathbf{\Delta E}$ & $\mathbf{a}^{* / \mathbf{b}^{*}}$ \\
\hline \multirow{2}{*}{ Organic } & Fresh & - & - & - & - & $1.08 \pm 0.00^{\mathrm{b}}$ \\
red pepper & 60 & $21.76 \pm 0.81^{\mathrm{a}}$ & $10.12 \pm 0.76^{\mathrm{f}}$ & $17.99 \pm 0.82^{\mathrm{ab}}$ & $30.00 \pm 1.17^{\mathrm{a}}$ & $0.85 \pm 0.01^{\mathrm{c}}$ \\
& 70 & $23.40 \pm 0.85^{\mathrm{b}}$ & $8.59 \pm 0.80^{\mathrm{e}}$ & $18.82 \pm 0.90^{\mathrm{bc}}$ & $31.25 \pm 0.97^{\mathrm{b}}$ & $0.79 \pm 0.03^{\mathrm{de}}$ \\
& 80 & $26.17 \pm 0.84^{\mathrm{c}}$ & $3.84 \pm 0.40^{\mathrm{b}}$ & $19.48 \pm 0.90^{\mathrm{c}}$ & $32.85 \pm 1.15^{\mathrm{c}}$ & $0.67 \pm 0.02^{\mathrm{f}}$ \\
\hline \multirow{2}{*}{ Conventional } & 60 & - & - & - & - & $1.16 \pm 0.00^{\mathrm{a}}$ \\
red pepper & 70 & $26.88 \pm 0.87^{\mathrm{cd}}$ & $6.29 \pm 0.66^{\mathrm{d}}$ & $18.33 \pm 0.57^{\mathrm{ab}}$ & $33.15 \pm 0.87^{\mathrm{cd}}$ & $0.79 \pm 0.03^{\mathrm{de}}$ \\
& 80 & $29.08 \pm 0.80^{\mathrm{e}}$ & $0.02 \pm 0.74^{\mathrm{a}}$ & $17.74 \pm 0.68^{\mathrm{a}}$ & $34.07 \pm 0.94^{\mathrm{d}}$ & $0.64 \pm 0.02^{\mathrm{a}}$ \\
\hline
\end{tabular}

Different letters in same column for organic and conventional peppers indicate significant differences $(p<0.05)$

Considerably higher changes in $\triangle \mathrm{a}^{*}$ values for both OSRP and CSRP powders were obtained at lower drying temperatures (Table 7). The improvement in the redness of the infrared dried OSRP samples were higher compared to CSRP samples. Whereas the change in yellowness $\left(\Delta b^{*}\right)$ values remained at a very limited level compared to 
the changes in redness $\left(\Delta \mathrm{a}^{*}\right)$ values. It is clear that increasing the drying temperature caused significant decrease in the $\mathrm{a}^{*}$ values of dried peppers (Table 6 ). In addition, increasing the drying temperature increased the $\mathrm{b}^{*}$ values of the OSRP powders while significantly reducing the $\mathrm{b}^{*}$ values of the CSRP powders $(p<0.05)$. This resulted in $\mathrm{a}^{*} / \mathrm{b}^{*}$ ratios of dried OSRP powders being higher than CSRP powders. Thus, the $\mathrm{a}^{*} / \mathrm{b}^{*}$ ratio given in Table 6 can be used to decide the best drying treatment for color quality. The highest $a^{*} / b^{*}$ ratio was obtained in OSRP samples dried at $60^{\circ} \mathrm{C}$. No significant difference was found among the $\mathrm{a}^{*} / \mathrm{b}^{*}$ ratio of CSRP samples dried at 60 and $70^{\circ} \mathrm{C}$ and OSRP samples dried at $70^{\circ} \mathrm{C}$. Hence, infrared drying at $60^{\circ} \mathrm{C}$ and $70^{\circ} \mathrm{C}$ can be evaluated as the acceptable drying applications in terms of color quality since they gave the nearest redness to yellowness ratios and higher brightness values as compared to the color parameters of fresh peppers which are desirable for the production of high quality dried sweet red pepper.

\section{Conclusions}

This research was carried out to compare the infrared drying characteristics of organically and conventionally produced sweet red peppers and to select the best drying application with respect to color quality. The results showed that the entire drying process for both organic (OSRP) and conventional sweet red peppers (CSRP) took place mainly in falling rate period. Increasing the drying temperature decreased the drying time considerably. Although the average drying time of CSRP samples lasted about one minute longer than OSRP, this difference was not statistically significant. Among the eleven models included in the study, the Midilli model gave the best fit for all data points for OSRP and CSRP samples. As expected, the drying coefficient $k$ increased with the increase in the drying temperature.

The effective moisture diffusivity $\left(D_{\text {eff }}\right)$ values of the OSRP samples were found slightly higher than those of the CSRP samples. The activation energies $\left(E_{a}\right)$ were computed as $30.85 \mathrm{~kJ} / \mathrm{mol}$ for the OSRP and $30.87 \mathrm{~kJ} / \mathrm{mol}$ for the CSRP samples. Both pepper samples showed almost same resistance to the moisture removed in the product as a result of infrared drying process. Growing practices (organic or conventional) of the same variety red peppers did not alter much of the profiles of moisture content versus drying time and drying rate versus moisture content, the drying coefficient $(k)$ data of Midilli model, effective moisture diffusivity and activation energy values all of which followed the similar trends. The OSRP samples dried at $60^{\circ} \mathrm{C}$ had the highest redness to yellowness ratio which denotes the deeper in red color. No significant differences were found among the redness to yellowness ratio of CSRP samples dried at $60^{\circ} \mathrm{C}$ and $70^{\circ} \mathrm{C}$ and OSRP samples dried at $70^{\circ} \mathrm{C}$.

Consequently, infrared drying at $60^{\circ} \mathrm{C}$ and $70^{\circ} \mathrm{C}$ can be evaluated as the acceptable drying applications in terms of color quality since they gave the nearest redness to yellowness ratios and higher brightness values as compared to the color parameters of fresh peppers, which is desirable for the production of high quality dried sweet red pepper powders. Infrared drying at $70^{\circ} \mathrm{C}$ resulted in about $22 \%$ savings in drying time and could be used to produce high quality organic or conventional sweet red pepper powder with better color quality. 


\section{References}

Aktaş, T., Orak, H. H., Şahin, F. H. (2013). Effects of different drying methods on drying kinetics and color parameters of strawberry tree (Arbutus unedo L.) fruit. Tekirdă̆ Ziraat Fakültesi Dergisi, 10(2), 1-12.

Anonymous, (2019a). FAOSTAT Crop production statistics database. Food and Agriculture Organization (FAO), http://www.fao.org/site, (Accessed date: 04.05.2020).

Anonymous, (2019b). Organic agricultural production data. Turkish Ministry of Agriculture and Forestry. https://www.tarimorman.gov.tr/Konular/Bitkisel-Uretim/Organik-Tarim/Istatistikler, (Accessed date: 03.05.2020).

Anonymous, 2018. Organic crop production statistics - 2018. Turkish Statistical Institute (TurkStat). http://www.tuik.gov.tr/UstMenu.do?metod=temelist, (Accessed date: 03.02.2020).

Arimboor, R., Natarajan, R. B., Menon, K. R., Chandrasekhar, L. P., Moorkoth, V. (2015). Red pepper (Capsicum annuum) carotenoids as a source of natural food colors: analysis and stability-a review. Journal of Food Science and Technology, 52(3), 1258-1271.

Arslan, D., Özcan, M. M. (2011). Dehydration of red bell-pepper (Capsicum annuum L.): Change in drying behavior, colour and antioxidant content. Food and Bioproducts Processing, 89(4), 504-513.

Asami, D. K., Hong, Y. J., Barrett, D. M., Mitchell, A. E. (2003). Comparison of the total phenolic and ascorbic acid content of freeze-dried and air-dried marionberry, strawberry, and corn grown using conventional, organic, and sustainable agricultural practices. Journal of Agricultural and Food Chemistry, 51(5), 1237-1241.

Cao, Z. Z., Zhou, L. Y., Bi, J. F., Yi, J. Y., Chen, Q. Q., Wu, X. Y., Zheng, J.K., Li, S. R. (2016). Effect of different drying technologies on drying characteristics and quality of red pepper (Capsicum frutescens L.): a comparative study. Journal of the Science of Food and Agriculture, 96(10), 3596-3603.

Chua, K. J., Chou, S. K. (2003). Low-cost drying methods for developing countries. Trends in Food Science \& Technology, 14(12), 519-528.

Crank, J. (1975). The mathematics of diffusion 2nd Edition. Oxford Science Publications, 32.

Darvishi, H., Asl, A. R., Asghari, A., Azadbakht, M., Najafi, G., Khodaei, J. (2014). Study of the drying kinetics of pepper. Journal of the Saudi Society of Agricultural Sciences, 13(2), 130-138.

Darvishi, H., Khoshtaghaza, M. H., Najafi, G., Nargesi, F. (2013). Mathematical modeling of green pepper drying in microwave-convective dryer. Journal of Agricultural Science and Technology, 15: 457-465.

Deng, L. Z., Yang, X. H., Mujumdar, A. S., Zhao, J. H., Wang, D., Zhang, Q., Wang, J., Gao, Z.J., Xiao, H. W. (2018). Red pepper (Capsicum annuum L.) drying: Effects of different drying methods on drying kinetics, physicochemical properties, antioxidant capacity, and microstructure. Drying Technology, 36(8), 893-907.

Di Scala, K., Crapiste, G. (2008). Drying kinetics and quality changes during drying of red pepper. LWT-Food Science and Technology, 41(5), 789-795.

Diamante, L. M., Munro, P. A. (1993). Mathematical modelling of the thin layer solar drying of sweet potato slices. Solar Energy, 51(4), 271276.

Doymaz, İ., İsmail, O. (2011). Drying characteristics of sweet cherry. Food and bioproducts processing, 89(1), 31-38.

Doymaz, İ., Kocayigit, F. (2012). Effect of pre-treatments on drying, rehydration, and color characteristics of red pepper (Charliston'variety). Food Science and Biotechnology, 21(4), 1013-1022.

Ergüneş, G., Tarhan, S. (2006). Color retention of red peppers by chemical pretreatments during greenhouse and open sun drying. Journal of Food Engineering, 76(3), 446-452.

Ertekin, C., Heybeli, N. (2014). Thin-layer infrared drying of mint leaves. Journal of Food Processing and Preservation, 38(4), 1480-1490.

Ertekin, C., Yaldiz, O. (2004). Drying of eggplant and selection of a suitable thin layer drying model. Journal of Food Engineering, 63(3), 349-359.

Gomiero, T. (2018). Food quality assessment in organic vs. conventional agricultural produce: findings and issues. Applied Soil Ecology, 123, 714-728.

Jain, D., Pathare, P. B. (2004). Selection and evaluation of thin layer drying models for infrared radiative and convective drying of onion slices. Biosystems Engineering, 89(3), 289-296.

Kadam, D. M., Goyal, R. K., Singh, K. K., Gupta, M. K. (2011). Thin layer convective drying of mint leaves. Journal of Medicinal Plants Research, 5(2), 164-170.

Keskin M., Soysal, Y., Sekerli, Y.E., Arslan, A., Celiktas. N. (2019). Assessment of applied microwave power of intermittent microwavedried carrot powders from Colour and NIRS. Agronomy Research. 17(2):466-480.

Keskin, M., Setlek, P., Demir, S. (2017). Use of Color Measurement Systems in Food Science and Agriculture. International Advanced Researches \& Engineering Congress. 16-18 November 2017, P.2350-2359 Osmaniye, Turkey (Abstract in English)

Keskin, M., Soysal, Y., Arslan, A., Sekerli, Y.E., Celiktas. N. (2018). Predicting Drying Temperature of Infrared-Dried Pepper Powders Using FT-NIRS and Chromameter. International Conference on Energy Research (ENRES2018), 31 October - 2 November 2018, P.305-319, Alanya, Turkey.

Kim, S., Park, J. B., Hwang, I. K. (2002). Quality attributes of various varieties of Korean red pepper powders (Capsicum annuum L.) and color stability during sunlight exposure. Journal of Food Science, 67(8), 2957-2961. 
Kim, S., Park, J., Hwang, I. K. (2004). Composition of main carotenoids in Korean red pepper (capsicum annuum, L) and changes of pigment stability during the drying and storage process. Journal of Food Science, 69(1), FCT39-FCT44.

Kumar, N., Sarkar, B. C., Sharma, H. K. (2011). Effect of air velocity on kinetics of thin layer carrot pomace drying. Food Science and Technology International, 17(5), 459-469.

Lernoud, J., Willer, H. (2019). Organic Agriculture Worldwide: Key results from the FiBL survey on organic agriculture worldwide 2019 Part 3: Organic agriculture in the regions.

Madamba, P. S., Driscoll, R. H., Buckle, K. A. (1996). The thin-layer drying characteristics of garlic slices. Journal of food engineering, 29(1), 75-97.

Maskan, A., Kaya, S., Maskan, M. (2002). Hot air and sun drying of grape leather (pestil). Journal of food engineering, 54(1), 81-88.

Midilli, A., Kucuk, H., Yapar, Z. (2002). A new model for single-layer drying. Drying technology, 20(7), 1503-1513.

Nasiroglu, S., Kocabiyik, H. (2009). Thin-layer infrared radiation drying of red pepper slices. Journal of Food Process Engineering, 32(1), 116.

Nowak, D., Lewicki, P. P. (2004). Infrared drying of apple slices. Innovative Food Science \& Emerging Technologies, 5(3), 353-360.

Onwude, D. I., Hashim, N., Chen, G. (2016). Recent advances of novel thermal combined hot air drying of agricultural crops. Trends in Food Science \& Technology, 57, 132-145.

Pawar, S. B., Pratape, V. M. (2017). Fundamentals of infrared heating and its application in drying of food materials: a review. Journal of Food Process Engineering, 40(1), e12308.

Rizvi, S. S. H. (1986). Thermodynamic properties of foods in dehydration. In: Engineering Properties of Foods, (M.A. Rao and S.S.H. Rizvi, eds.), Marcel Dekker, New York, pp. 190-193.

Sablani, S. S., Andrews, P. K., Davies, N. M., Walters, T., Saez, H., Bastarrachea, L. (2011). Effects of air and freeze drying on phytochemical content of conventional and organic berries. Drying Technology, 29(2), 205-216.

Sandu, C. (1986). Infrared radiative drying in food engineering: a process analysis. Biotechnology Progress, 2(3), 109-119.

Sanjuán, N., Lozano, M., García-Pascual, P., Mulet, A. (2003). Dehydration kinetics of red pepper (Capsicum annuum L var Jaranda). Journal of the Science of Food and Agriculture, 83(7), 697-701.

Saravacos, G. D. (1986). Mass transfer properties of foods. In: Rao, M. A., Rizvi, S. S. H., editors. Engineering properties of foods. New York: Marcel Dekker Inc. p 89-132.

Soysal, Y., Ayhan, Z., Eştürk, O., Arıkan, M. F. (2009). Intermittent microwave-convective drying of red pepper: Drying kinetics, physical (colour and texture) and sensory quality. Biosystems Engineering, 103(4), 455-463.

Soysal, Y., Keskin, M, Arslan, A., Sekerli, Y.E. (2018). Infrared Drying Characteristics of Pepper at Different Maturity Stages. International Conference on Energy Research (ENRES 2018), 31 October - 2 November 2018, Alanya, Turkey.

Soysal, Y., Öztekin, S., Eren, Ö. (2006). Microwave drying of parsley: modelling, kinetics, and energy aspects. Biosystems Engineering, 93(4), 403-413.

Soysal, Y., Oztekin, S., Isıkber, A. A., Duman, A. D., Dayısoylu, K. S. (2005). Assessing the colour quality attributes of Turkish red chilli peppers (Capsicum annuum L.) and colour stability during storage. In Proceedings of the 9th International Congress on Mechanization and Energy in Agriculture, P.99-104, Izmir, Turkey.

Şahin, F. H., Ülger, P., Aktaş, T., Orak, H. H. (2012). Farklı Önişlemlerin ve Vakum Kurutma Yönteminin Domatesin Kuruma Karakteristikleri ve Kalite Kriterleri Üzerine Etkisi. Tekirdağ Ziraat Fakültesi Dergisi, 9(1), 15-25.

Thuwapanichayanan, R., Prachayawarakorn, S., Kunwisawa, J., Soponronnarit, S. (2011). Determination of effective moisture diffusivity and assessment of quality attributes of banana slices during drying. LWT-Food Science and Technology, 44(6), 1502-1510.

Topuz, A., Dincer, C., Özdemir, K. S., Feng, H., Kushad, M. (2011). Influence of different drying methods on carotenoids and capsaicinoids of paprika (Cv., Jalapeno). Food chemistry, 129(3), 860-865.

Tunde-Akintunde, T., Oyelade, O., Akintunde, B. (2014). Effect of drying temperatures and pre-treatments on drying characteristics, energy consumption, and quality of bell pepper. Agricultural Engineering International: CIGR Journal, 16(2), 108-118.

Turhan, M., Turhan, K. N., Sahbaz, F. (1997). Drying kinetics of red pepper. Journal of food processing and preservation, 21(3), 209-223.

Vega-Gálvez, A. L. M. S., Lemus-Mondaca, R., Bilbao-Sáinz, C., Fito, P., Andrés, A. (2008). Effect of air drying temperature on the quality of rehydrated dried red bell pepper (var. Lamuyo). Journal of Food Engineering, 85(1), 42-50.

Vega-Gálvez, A., Di Scala, K., Rodríguez, K., Lemus-Mondaca, R., Miranda, M., López, J., Perez-Won, M. (2009). Effect of air-drying temperature on physico-chemical properties, antioxidant capacity, colour and total phenolic content of red pepper (Capsicum annuum, L. var. Hungarian). Food Chemistry, 117(4), 647-653.

Verma, L. R., Bucklin, R. A., Endan, J. B., Wratten, F. T. (1985). Effects of drying air parameters on rice drying models. Transactions of the ASAE, 28(1), 296-0301.

Wang C. Y., Singh R. P. (1978). A single layer drying equation for rough rice. ASAE Paper No: 78-3001, ASAE, St. Joseph, MI.

Wang, Z., Sun, J., Chen, F., Liao, X., \& Hu, X. (2007). Mathematical modelling on thin layer microwave drying of apple pomace with and without hot air pre-drying. Journal of Food Engineering, 80(2), 536-544.

Winter, C. K., Davis, S. F. (2006). Organic foods. Journal of Food Science, 71(9), R117-R124. 
Arslan \& Soysal \& Keskin

Infrared Drying Kinetics and Color Qualities of Organic and Conventional Sweet Red Peppers Yagcioglu, A., Degirmencioglu, A., Cagatay, F.1(999). Drying characteristics of laurel leaves under different drying conditions. Proceedings of $7^{\text {th }}$ International Congress on Agricultural Mechanization and Energy in Agriculture, P.565-569, Adana, Turkey.

Zogzas, N. P., Maroulis, Z. B., Marinos-Kouris, D. (1996). Moisture diffusivity data compilation in foodstuffs. Drying technology, 14(10), $2225-2253$. 